\title{
The Impact of the Saudi New E-Commerce Law on Protecting E-Commerce Investments in Saudi Arabia
}

\author{
Faris M. Algarni
}

Saudi Electronic University, Kingdom of Saudi Arabia

\begin{abstract}
On July $10^{\text {th }} 2019$, the Kingdom of Saudi Arabia adopted its new law for investors and customers engaged in e-commerce. This current article addresses a number of issues related to the protection of e-commerce investors in Saudi Arabia. The study employed a quantitative method, through the use of questionnaires. Its main focus was on investors' views of the benefits of this new Saudi law, in order to establish whether there remains any need for further reform to convince both existing and potential foreign investors to invest in Saudi e-commerce. The respondents were asked to state their level of satisfaction with the current law of e-commerce and suggest the kind of reforms required to enhance the attractiveness of the Kingdom as an e-commerce investment environment.
\end{abstract}

The key findings of this research are that firstly, the law of e-commerce is a core factor in the decision of investors to continue investing in the Saudi Arabian e-commerce market. Secondly, a number of the respondents were not fully satisfied with the new law, believing that it offered more protection to customers than investors. Thirdly, this led to the suggestion of the implementation of a number of legal reforms, to be included as part of a proposed new bylaw of e-commerce. The aim of this inclusion is to attract continued investment into e-commerce in the Kingdom.

Keywords: E-commerce, Law, Investors, Protection, Saudi Arabia

\section{Introduction}

A technological revolution has taken place over the previous decade in response to the rapid increase in the use of the Internet and different web technologies, including various applications. E-commerce forms an important aspect of this revolution and is now widely employed for global trade. E-commerce has been described as the "supply of goods or services, normally provided upon remuneration, at a distance, by means of electronic equipment for the processing and storage of data, at the individual request of a recipient of the service" (The European Parliament and Council Directive 2000/31, 2000, p.178).

E-commerce has revealed a number of significant benefits, prompting its adoption by developed countries as a part of their business activities. Many developing countries (including the Kingdom of Saudi Arabia) have also expressed a wish to adopt e-commerce to join the world information-based economy. The reports of the Communications and Information Technology Commission for the third quarter of 2016 demonstrated an increase in the number of Internet users in the Kingdom of Saudi Arabia between 2014 and 2016 from 19.6 million to 24 million (Alarabiya Network, 2016). This increase has had a significant impact on the growth of ecommerce in the Kingdom, which is now estimated to have risen from approximately six billion USD in 2015 to around eleven billion USD in 2020 (Go-Golf Network, 2015).

In addition, Saudi Vision 2030 supports this form of economic growth in the e-commerce sector. This has led to Saudi Arabia's Public Investment Fund to join with a UEA partner to launch the largest e-commerce platform in the Arab region, known as Noon.com (Alarabiya Network, 2016). The Public Investment Fund led by the 
Crown Prince is therefore now focusing on the use of e-commerce to fulfil one of the main goals of Vision 2030, i.e. to diversify Saudi income resources.

Various countries have put in place laws to govern e-commerce transactions. The contribution and potential of e-commerce, both socially and economically, have offered a number of motives for policymakers and other stakeholders. Thus, various guidelines, regulations, and treaties have been adopted and plans developed for increasing e-commerce throughout the world. International organizations (i.e. OECD and UNCITRAL) have expressed a willingness to participate in the regulation of e-commerce. UNCITRAL adopted a Model Law of Electronic Commerce in 1996, while OECD set out its 'Guidelines on e-Commerce' (1999). It is essential for a country to establish legislation meeting the needs of e-commerce business and consumers. These laws raise different legal issues in the environment of e-commerce, including the validity of contracts, the time and place of communication and cross offers. There are also a further three areas in which the law exerts a significant influence on e-commerce: (1) intellectual property: (2) jurisdiction; and (3) defamation. The importance of ecommerce laws is their ability to recommend the establishment of efficient and flexible policies in accordance with the needs of each individual country, along with the appropriate principles and practices for business-tobusiness and business-to-consumer relationships in e-commerce.

In principle, the promotion of e-commerce in any state depends on more than one factor. One of the main issues relates to the relevant regulations, resulting many countries aiming to create a suitable environment for ecommerce, including making periodic changes to their regulations to minimize the challenges facing investors in e-commerce.

This article firstly, examines Saudi e-commerce law and its impact on the protection of e-commerce investors in order to determine whether the Saudi legal system is in need of reform to ensure the attractiveness of the ecommerce environment. Secondly, it develops a practical and legal vision of the impact of the Saudi ecommerce regulations on the protection of e-commerce investors. Thirdly, it discusses whether aspects of protection approved by the law are sufficient, or if e-shop owners require additional guarantees to ensure a profitable return.

\section{Research Questions}

This paper answers the following questions:

- Does the new Saudi e-commerce law protect e-commerce investments?

- Is there any need to reform the legal environment of e-commerce in Saudi Arabia?

- What are the reforms needed to improve the legal framework of e-commerce?

\section{Literature Review}

There are a number of studies discussing e-commerce from legal perspective. Some focus on the global view, while other focus specifically on developing countries. These studies highlight the different legal issues currently hindering some countries from establishing an attractive e-commerce environment. Farhoomand, Tuunainet and Yee (2000) identified six barriers to global e-commerce: (1) ensuring the privacy of users; (2) 'advertising; (3) copyright laws: (4) issues concerning the legitimacy of electronic signatures; (5) ISPs' responsibilities; and (6) cryptography and public key encryption' (Farhoomand et al., 2000)

A number of studies using secondary data have concluded that the legal environment of a country has a considerable impact on the activities and revenues of e-commerce. (Ndubizu and Arinze, 2002). In addition, various firm-level studies using questionnaires have also found that the legal environment is significantly 
beneficial for determining both the breadth and depth of the adoption e-commerce, particularly in developing states and the new industrialized economies. (Gibbs and Kraemer, 2004; Zhu, Kraemer, Xu, and Dedrick, 2004.) Moreover, Kapurubandara and Lawson (2006) divided the barriers of e-commerce in developing countries into internal and external, emphasising that an external barrier is legal and regulatory, i.e. having an insufficient legal framework for e-commerce.

The literature reveals legal barriers to be major obstacles to e-commerce in developing countries. A survey conducted in Brazil indicated that the low rate of e-commerce adoption related to: (1) government regulations concerning privacy and security; (2) a lack of business laws for e-commerce: (3) inadequate legal protection for local purchases; and (4) issues linked to internet taxation (Tigre \& Dedrick, 2004). Furthermore, in China, a lack of 'transactional and institutional trust' related to the weakness of the rule of laws was found to be a major impediment to e-commerce (Efendioglu \& Yip, 2004).

Gabriel (2013) focused on the special nature of e-commerce, accentuating the need for its regulation, in order to ensure it offers more benefits than problems. He noted that existing legislation regulating e-commerce in developed countries tends be implemented in relation to the scope of the UNCITRAL and Model Law on Electronic Commerce 1996, including: (1) the United States of America (The American Uniform Electronic Transactions Act, 1999); (2) Canada (The Canadian Uniform Electronic Commerce Act, 1999); and (3) Australia (The Australian Electronic Transactions Act, 1999). In addition, Gabriel's (2004) discussion of the salient clauses of various laws regulating e-commerce in different countries has identified issues concerning electronic contracting. This has resulted in recommendations to address the shortcomings identified in these regulations.

Several studies have discussed e-commerce in the Kingdom of Saudi Arabia from a number of different dimensions. Some, such as 'E-Commerce in Saudi Arabia: Acceptance and Implementation Difficulties' conducted by Makki \& Chang (2014), are not legal in nature, but identify the importance of regulations of ecommerce in the Kingdom. This study concluded that Saudi companies are discouraged from establishing an online retail system by the lack of clear rules and regulations relating to e-commerce (Makki \& Chang, 2014). In addition, the researchers stated that "e-commerce government rules and regulations apparently are the most significant inhibitors to e-commerce in Saudi Arabia to consumers, retailers and sometimes to banks" (Makki \& Chang, 2014). This view is supported by the lack of specific Saudi legislation being put in place until July 2019 focusing on e-commerce commensurate with that adopted in other countries in the region. However, due to the new Saudi Law on e-commerce having only been recently adopted, no study has yet discussed this law in depth.

Following the 1990s, there has been much debate concerning the development of policies to create a supportive environment for the global adoption of e-commerce (Zhu, 2009). The Kingdom of Saudi Arabia therefore needs to examine its current laws related to e-commerce, in order to help policy makers address the concerns expressed in the responses of the respondents of this current study. This article will therefore contribute to new information concerning the reaction of investors to the new e-commerce law in the Kingdom. In addition, it addresses the research gap left by the fact that most current studies focus on the protection of consumers, as it focusses instead on investors' protection of their investments in e-commerce.

\section{Methodology}

A qualitative approach has been used for the primary exploration research of this study. This approach assists in establishing a profound understanding of e-Commerce investors in Saudi Arabia. An electronic questionnaire was sent to a number of e-commerce investors, whose details were located in Maroof, a known reliable platform authorised by the Saudi Ministry of Commerce and Investment. As stated in the website of the Saudi Ministry of Commerce and Investment (2016), Maroof is "expected to be one of the best ways to consider and evaluate the electronic stores in the Kingdom, which will benefit all dealers of this e-commerce, either sellers or buyers, and thus supporting the e-commerce and the electronic shops, and their reliability would be increased." 
The questionnaire focused on eliciting replies to establish the findings of this article. The first question concerned the satisfaction of e-commerce investors with the current legal protection in the Saudi law of ecommerce. The second question raised the concerns expressed by e-commerce investors that have not been addressed by the existing e-commerce law. Finally, investors were questioned about proposed legal reforms in order to establish whether the new e-commerce law would encourage them to invest in e-commerce.

The responses provided an overview of the changes suggested by investors as improvements to the current legal system related to e-commerce in Saudi Arabia. Chart 1 (below) demonstrates that the respondents came from several different e-commerce sectors, with most taking part in e-marking activities. 33\% of the respondents invested in various activities, while 17\% invested in women's accessories and the remainder invested in occasions and celebrations.

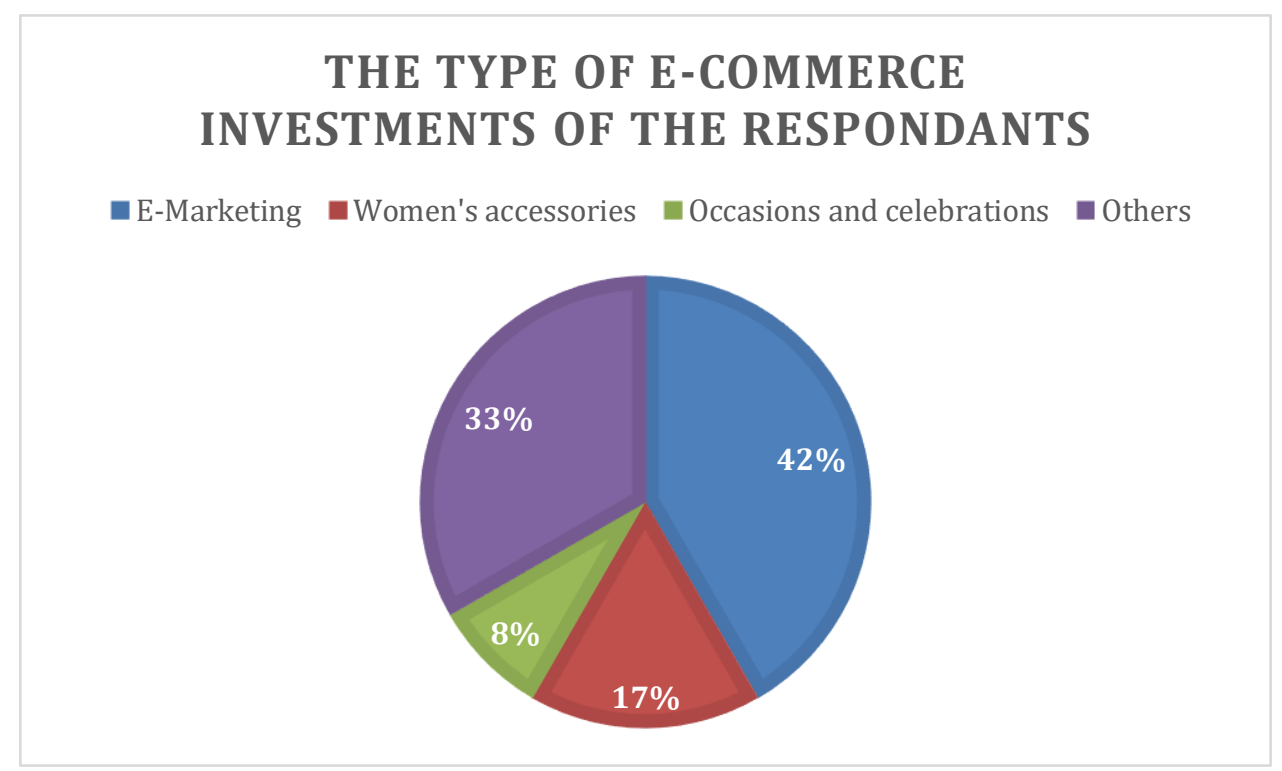

Chart 1: The Percentage of respondents from differing e-commerce sectors.

In addition, Chart 2 (below) demonstrates that all the respondents had invested in e-commerce for over a period of a year, with $33 \%$ having invested for over five years. This indicates that they were all highly aware of the reforms needed to improve the e-commerce legal environment, and that this article was able to achieve an accurate result.

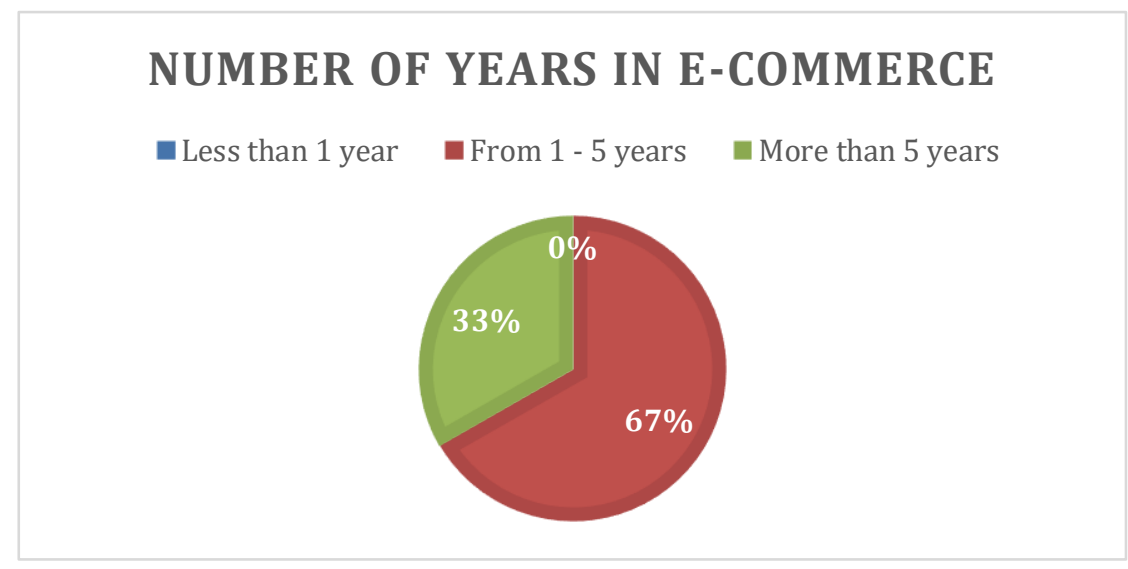

Chart 2: The duration of the investment of the respondents in e-commerce by years 


\section{Results and Discussion}

The above discussion reveals that Saudi laws and regulations pertaining to e-commerce seek to achieve a number of goals, i.e. protecting the rights of intellectual property and personal data. The legal framework attempts to cover several legal aspects of internet ecosystem, including banking, privacy and telecommunications. Consequently, various governmental bodies have taken part in enforcement responsibilities, in order to ease the procedures of e-commerce. The ensuing legal framework consists of a variety of rules, in addition to the e-commerce law enacted by the Saudi government relating to 'spam' emails, domain names, cyberspace and online content.

Chart 3 (below) demonstrates that approximately $25 \%$ of the respondents considered that the Saudi new law of e-commerce had failed to provide them with the necessary protection, while 17\% claimed that the e-commerce law protected their investment. However, most respondents chose the answer 'Maybe', thus indicating uncertainty as to whether the law offers sufficient protection for their investments. This emphasises that investors remain unsure of the impact of the regulations on their e-commerce investments. Several studies have identified the Saudi government's regulations on e-commerce as a factor influencing the evolution of ecommerce in the Kingdom of Saudi Arabia. (Alghamdi, Drew and Alhussain, 2012) Therefore, existing uncertainty concerning the advantages of the new regulations could hinder an evolution of e-commerce, so highlighting the need to clarify the extent to which these laws can assist in offering protection to investments. Government declarations have confirmed that the regulations provide protection to consumers and preserves their rights. However, there also is an urgent need to outline the ways this new law of e-commerce can attract addition investments by both local and foreign investors. This uncertainty over the existing level of protection offered to e-commerce investment may discourage both foreign and local investors from investing, or continuing to invest. This is significant, as Saudi Vision 2030 depends on attracting foreign investment as a significant means of reducing the Kingdom's current dependence on oil. This issue therefore needs to be reconsidered by the Saudi Council of e-commerce led by the Saudi Minister of Commerce.

This highlights that as noted by Gibbs, Kraemer, and Dedrick, (2003), the promotion policies appear to be more important than e-commerce regulations per se, as a number of country cases have concluded that e-commerce is indeed taking place with no specific e-commerce regulations. However, such cases demonstrate that trust, privacy, and financial safeguards are important factors in consumers' engagement with e-commerce, and inadequate legislation may therefore hinder its development (Gibbs, Kraemer, and Dedrick, 2003). The Chinese Government, for example, has adopted policies to encourage e-commerce adoption, although there is a concern that regulations may have a negative impact ( $\mathrm{Li}$ and $\mathrm{Xie}, 2012)$. Based on that discussion, policies may provide more protection that regulations in the Kingdom of Saudi Arabia. This needs to be considered carefully in order to extend the space of contentment about the protection given by the Saudi e-commerce law. So, the ecommerce law can represent such promotion policies in its content with high rule of law in the Kingdom.

The importance of the rule of law is magnified in e-commerce by the different types of risks accompanying online transactions. Purchasers face the potential to experience fraud, as they have no assurance that they will obtain the goods for which they have paid, or if their credit card number or other information is being collected. They also do not have a physical location to return defective products, or have access to a personal conversation if any issue arises. In addition, traders can also be defrauded by buyers, particularly if goods are shipped prior to payment, as is common in business-to-business sales (Shih, Dedrick, and Kraemer, 2005). Regulations are therefore likely to play a particularly significant role in minimising the risks of e-commerce, reassuring both buyers and sellers that they have complete legal protection in the case of "online fraud, effective punishment lowers the cost of reputation building for honest businesses, and people have a higher degree of trust in remote market transactions" (Oxley and Yeung, 2001, p.712) 
Due to e-commerce requiring companies to engage in remote transactions, the extent to which regulations ensure legal protection, and thus increase trust in contracting, increases the favourability of the market. Thus, countries with weak and ineffectively enforced commercial laws and rules may be slow to develop, despite having the necessary circumstances, i.e. availability of investment capital and high credit card penetration. This is because consumers may lack the confidence to engage in any online transactions with less well-known companies, due to the potential for misconduct accompanied by a lack of legal recourse if they are not satisfied. However, countries with strong rule of law, should see more influence from other determinants, because dissatisfied customers are able to seek remediation through legal means and be more willing to enter into online transactions. From the side of buyers, this highlights that a strong rule of law, accompanied by suitable regulations, can help foster conditions encouraging the growth of e-commerce (Shih, Dedrick, and Kraemer, 2005).

The said conclusion is also noted by Oxley and Yeung (2001). They argued that the diffusion of e-commerce technologies depends on a variety factors related to economy and policy, including the rule of law, which can be defined as the institutional environment setting the conditions for economic investment and exchange. In addition, it contains "an impartial court system, legal protection of property rights, enforceable contract laws, and citizens who have confidence in the legitimacy of these institutions and accept their authority in resolving disputes" (Oxley and Yeung, 2001).

\section{THE IMPACT OF THE NEW E-COMMERCE REGULATIONS ON ON THE PROTECTION OF E- COMMERCE INVESTMENTS IN SAUDI ARABIA}

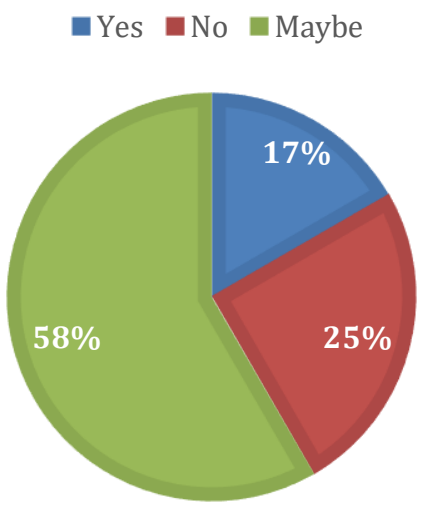

Chart 3. Respondents' view of the protection offered by the new e-commerce law to their e-commerce investments

In fact, there is a significant need for regulations to be effectively enforced in relation to e-commerce, particularly for conflict resolution, which forms part of the protection given to all e-commerce investors in the Kingdom. The new regulations do not specify this subject, highlighting the need for the new bylaw to be enacted by the Saudi Cabinet in the coming months. On the other hand, some respondents reported that they felt the new e-commerce regulations offered more support to consumers than investors. However, since the government plays a key role in the e-commerce environment, protection and security regulations must be provided to both consumers and retailers. Policy makers in the Kingdom of Saudi Arabia should therefore play a more active role in resolving the issues of consumer and investors.

Table 1 (below) demonstrates suggestions from the respondents, focussing particularly on issues related to ecommerce. From the legal perspective, some respondents considered current payment rules to be unclear, needing to be clarified within e-commerce law. Others noted a lack of protection to investors' contracts with 
shipping companies. It should be noted that the current e-commerce law does not address this issue. Additionally, one of the respondents stated that the rules relating to the delivery of products to customers must be improved to protect both investors and customers of e-commerce. Alghamdi, Drew and Alhussain (2012) noted that the progress of the implementation of e-commerce in the Kingdom of Saudi Arabia has been influenced by a number of factors, including "secure and trusted online payment methods, consumer protection, market place regulations, certification authority and delivery systems" (p. 142). The respondents' answers emphasize that there is an urgent need for profound changes in the reality of e-commerce in the Kingdom.

Table 1: Respondents' answers concerning their needs as investors in the e-commerce sector in the Kingdom

\begin{tabular}{|l|}
\hline What do you need as an e-commerce investor? \\
\hline $\begin{array}{l}\text { A clear law from the Ministry of Commerce, in addition to banking facilities } \\
\text { because they ask for real shops not e-shops. }\end{array}$ \\
\hline More logistic services related to payment and delivery. \\
\hline Quick access to the target customer. \\
\hline Facilitating government procedures. \\
\hline İncreasing consumers' familiarity with electronic payment. \\
\hline More competitive advantages for local merchants over foreign merchants. \\
\hline More protection for e-commerce investors on social networking sites. \\
\hline $\begin{array}{l}\text { Facilitating more comfortable payment methods for individuals, not limited to } \\
\text { companies. }\end{array}$ \\
\hline Increasing awareness of electronic payment. \\
\hline $\begin{array}{l}\text { The most important of which are the rights to ethics of dealing, as well as } \\
\text { returns, as well as our protection from shipping companies and their } \\
\text { exploitation and abuse. Likewise, most of the regulations protect the consumer, } \\
\text { not the investor. }\end{array}$ \\
\hline Ensuring investors' rights, following the confirmation of consumer rights. \\
\hline More flexibility in financing e-commerce investments. \\
\hline Constant monitoring of service providers for electronic stores. \\
\hline Applying strict fraud protection system. \\
\hline
\end{tabular}

The mentioned needs of the respondents demonstrate the current barriers to e-commerce in the Kingdom which go beyond the legal aspects. This can be seen in various countries in the World with different types of barriers. Inequality of socioeconomic levels can act to set long term limits to e-commerce markets, being particularly acute in countries such as Brazil and Mexico. (Gibbs, Kraemer, and Dedrick, 2003). Other countries may have: (1) a lack of valuable and useful content for consumers; (2) inequality of socioeconomic levels; and (3) concerns related to security/privacy. In addition, the lack of truly useful content on the Internet (i.e. products and services) is a major impediment to the current use of e-commerce in some countries (Gibbs, Kraemer, and Dedrick, 2003). This arises from security and privacy concerns proving a barrier in states having no financial and legal protection in place (Gibbs, Kraemer, and Dedrick, 2003).

As noted, the above findings reveal a lack of satisfaction among the respondents with the new law of ecommerce in Saudi Arabia. This gives an importance to the responses of the respondents regarding their suggestions to improve the legal environment of e-commerce in the Kingdom. Table 2 (below) illustrates a number of suggestions. It can be seen that the infrastructure of e-commerce continues to require improvement. Most responses relate to: (1) Internet speed; (2) the e-payment system; (3) the shipping services; and (4) the 
import and export of goods. Each of those reforms must be taken into account by lawmakers in Saudi Arabia. These reforms are fully or partially related to the regulations of e-commerce. It also important for the lawmakers to understand that such regulations have an influence on the entry, operation, and exit of e-commerce investors. The legal protection for e-commerce investors in Saudi Arabia is needed in all these stages.

The investors' responses in chart 3 are reflected in table 2. So, the low percentage of satisfaction means that there are a number of reforms have to be done in order to improve e-commerce environment. The Saudi Government should therefore find a way of minimising the concerns of e-commerce investors, in order to ensure a safer and more attractive e-commerce environment.

Table 2: Answers of the respondents to the reforms suggested to e-commerce sector in the Kingdom

\begin{tabular}{|l|}
\hline What are the Reforms you suggest to improve the e-commerce environment? \\
\hline Reducing the control of big e-stores, so that small stores can flourish. \\
\hline $\begin{array}{l}\text { Developing e-payment applications without the need for a traditional bank } \\
\text { transfers. }\end{array}$ \\
\hline Maximising the speed of site search in Saudi Arabia. \\
\hline Facilitating import and export activity. \\
\hline Accelerating the reform of digital infrastructure. \\
\hline $\begin{array}{l}\text { Deep understanding to be developed by the Zakat and Income Authority of the } \\
\text { e-commerce sector. }\end{array}$ \\
\hline Having a documented database of e-commerce in the Ministry of Commerce. \\
\hline $\begin{array}{l}\text { Providing opportunities for world-famous platforms to fully enter the Saudi } \\
\text { market. }\end{array}$ \\
\hline Developing logistics and shipping services. \\
\hline $\begin{array}{l}\text { Monitoring the websites of auctions to minimize fraud, lying, counterfeit goods } \\
\text { and loss of rights. }\end{array}$ \\
\hline Addressing the lack of shipping companies \\
\hline $\begin{array}{l}\text { Further facilitating electronic and banking services related to electronic } \\
\text { commerce. }\end{array}$ \\
\hline Clear system of shipping companies. \\
\hline
\end{tabular}

\section{Conclusion and Recommendations}

This paper has demonstrated that electronic commerce has the potential to be one of this century's greatest economic developments and is already revolutionising methods of doing business. It contributes significantly to the literature of e-commerce in the Kingdom of Saudi Arabia through the discussion of the protection offered to investment by Saudi e-commerce law. The paper illustrated the impact of the global development of technology on the number of e-commerce customers in Saudi Arabia, which has encouraged many investors to enter the ecommerce market to increase their competitiveness. Furthermore, the data revealed that respondents did not view the current level of protection offered to e-commerce investments in Saudi Arabia as being sufficiently strong, highlighting a need to take legal strategies into account in building the desired trust and confidence for traders.

This study also discussed a number of reforms proposed by the respondents to firstly, create an attractive environment of e-commerce and secondly, provide additional investment protection in the Kingdom of Saudi 
Arabia. It acknowledged that the Kingdom is now working to strengthen its e-commerce system as one of its objectives in the National Transformation Programme, with the aim of fulfilling Vision 2030.

This paper therefore concludes that the Saudi government should reconsider the law of e-commerce, in order to ensure it becomes more suitable for investors. In addition, there is further scope for researchers with an interest in e-commerce to write articles focusing on some of the issues raised by the respondents of this study, i.e. the rules of payment and delivery. Furthermore, this study has established the need to create clear rules of delivery and shipment to help investors protect their investments. A number of future studies could be undertaken from the perspective of the policy makers, as well as consumers, in terms of the new e-commerce law in the Kingdom, in order to enhance the literature concerning e-commerce. This would require greater assistance to researchers from government agencies, in particular by providing information that will assist them in examining different aspects of e-commerce.

\section{References}

AlGhamdi, R., Drew, S. and Alhussain, T. (2012). A Conceptual Framework for the Promotion of Trusted Online Retailing Environment in Saudi Arabia, Int. J. Bus. Manag. vol. 7, no. 5, pp. 140-150, Feb. 2012

Al Arabiya Network. (2016). Saudi Arabia amongst the Countries having a Huge Growth in E-Commerce. Retrieved from http://www.alarabiya.net/ar/aswaq/economy/2016/12/09/\%D8\%A7\%D9\%84\%D8\%B3\%D9\%88\%D9\%82\%D8\%A7\%D9\%84\%D8\%B3\%D8\%B9\%D9\%88\%D8\%AF\%D9\%8A\%D8\%A9-\%D8\%B6\%D9\%85\%D9\%86\%D8\%A3\%D9\%83\%D8\%A8\%D8\%B1-\%D8\%A7\%D9\%84\%D8\%A3\%D8\%B3\%D9\%88\%D8\%A7\%D9\%82\%D9\%86\%D9\%85\%D9\%88\%D8\%A7\%D9\%8B-\%D9\%81\%D9\%8A\% $8 \%$ A7\%D9\%84\%D8\%AA\%D8\%AC\%D8\%A7\%D8\%B1\%D8\%A9\%D8\%A7\%D9\%84\%D8\%A5\%D9\%84\%D9\%83\%D8\%AA\%D8\%B1\%D9\%88\%D9\%86\%D9\%8A\%D8\%A9.h $\mathrm{tml}$

Al Arabiya Network. (2016). Saudi Arabia investing in largest Arab e-commerce platform'. Retrieved from http://english.alarabiya.net/en/business/retail/2016/11/13/Saudi-Arabia-investing-in-largest-Arab-e-commerceplatform.html

Efendioglu, A. \& Yip, V. (2004). Chinese culture and e-commerce: An exploratory study. Interacting with Computers, 16, pp.45-62. Retrieved from http://www.oecd.org, Electronic Commerce - About electronic commerce)

Farhoomand, A. F., Tuunainet, V. K. and Yee, L. W. (2000). Barriers to Global Electronic Commerce: A CrossCountry Study of Hong Kong and Finland. Journal of Organizational Computing and Electronic Commerce 10(1): 23-48.

Gabriel H.D (2004). The Fear of the Unknown: The Need to provide special procedural protections in international electronic commerce ' 50 Loy. L. Rev. 307 2004, accessed at (http://heinonline.org) on Fri Mar 1 08:15:43 2013.

Gibbs, J., Kraemer, K.L. and Dedrick, J. (2003). Environment and policy factors shaping global e-commerce diffusion: a cross-country comparison, The Information Society, 19(1), pp. 5-18.

Gibbs, J. L. and Kraemer, K. L. A (2004). Cross-country investigation of the determinants of scope of ecommerce use: an institutional approach, Electronic Markets, 14, pp. 124-137, June 2004.

Go-Golf Network. (2015). E-Commerce in Saudi Arabia - Statistics and Trends. Retrieved from http://www.gogulf.com/blog/ecommerce-saudi-arabia/

Kapurubandara, M., and Lawson, R. (2006). Barriers to adopting ICT and e-commerce with SMEs in developing countries: an exploratory study in Sri Lanka. Proceedings of the 2006 Collector Conference on Electronic Commerce. Retrieved from https://www.semanticscholar.org/paper/Barriers-to-adopting-ICT-and-ecommerce-with-SMEs-\%3A-Kapurubandara-Lawson/0d5bffb6dbcddef64b4cd9835f2c182e94094ab2 
Li, P. and Xie, W., A. (2012). Strategic framework for determining e-commerce adoption, Journal of Technology Management in China, 7(1), 2012 pp. 22-35

Makki, E. and Chang, L. (2014). E-Commerce in Saudi Arabia: Acceptance and Implementation Difficulties. Proceedings of the 2014 International Conference on e-Learning, e-Business, Enterprise Information Systems, and e-Government (EEE'14), Las Vegas, NV, USA

Ndubizu and Arinze, B. (2002). Legal determinants of the global spread of e-commerce, International Journal of Information Management, 22, pp. 181-194.

Oxley, J.E. and Yeung, B. (2001). E-commerce readiness: institutional environment and international competitiveness. Journal of International Business Studies 32(4)(2001), pp.705-723

Saudi Ministry of Commerce and Investment. (2016). MAROOF: An initiative to support e-commerce in the Kingdom. Retrieved from https://mci.gov.sa/en/MediaCenter/News/Pages/17-04-16-01.aspx

The European Parliament and Council Directive 2000/3 I/EC, concerning certain legal aspects of information society services, in particular electronic commerce, in the internal market, OJ L 178, 17 October 2000, 0001 0016

Shih, C.-F., Dedrick, J. and Kraemer, K.L. (2005). Rule of law and the international diffusion of e-commerce. Association for Computing Machinery Communications of the ACM, 48(11), pp. 57-62.

Tigre, S.B. and Dedrick, J. (2004). E-commerce in Brazil: Local adaptation of a global Technology, Journal Electronic Markets, 14(1), pp.36-47

Zhu, K. Kraemer, K.L., Xu, S. and Dedrick, J. (2004). Information technology payoff in e-business environments: An international perspective on value creation of e-business in the financial services industry, Journal of Management Information Systems, 21(Summer), pp. 17-54.

Zhu, L. (2009). Legal and Policy Environments: An Institutional Perspective of Global E-commerce Adoption. Proceedings of the 42nd Hawaii International Conference on System Sciences. 